\title{
Ecophysiology and respiratory metabolism during the germination of Inga sessilis (Vell.) Mart. (Mimosaceae) seeds subjected to hypoxia and anoxia ${ }^{1}$
}

\author{
JANETE MAYUMI OKAMOTO ${ }^{2}$ and CARLOS ALFREDO JOLY ${ }^{2,3}$
}

(received: May 27, 1999; accepted: November 17, 1999)

\begin{abstract}
Ecophysiology and respiratory metabolism during the germination of Inga sessilis (Vell.) Mart. (Mimosaceae) seeds subjected to hypoxia and anoxia). This paper presents a study on the respiratory metabolism of germinating seeds of Inga sessilis subjected to normoxia, hypoxia and anoxia. Although it is typical of environments where waterlogging seldom occurs, $40 \%$ of its seeds are able to germinate under hypoxia; yet, anoxia periods over $96 \mathrm{~h}$ are lethal to the seeds. Ethanol is the main product of the seeds anaerobic metabolism, but the steep increase in lactate after $24 \mathrm{~h}$ anoxia or $48 \mathrm{~h}$ hypoxia may explain the drop in seed viability.
\end{abstract}

RESUMO - (Ecofisiologia da germinação e metabolismo respiratório de sementes de Inga sessilis (Vell.) Mart. (Mimosaceae) submetidas à hipoxia e anoxia). Os estudos referentes à germinação e ao metabolismo respiratório de sementes de Inga sessilis (Vell.) Mart. submetidas a normoxia, hipoxia e anoxia, mostraram que apesar de ser uma espécie típica de ambientes com solos bem drenados, $40 \%$ das sementes germinam sob hipoxia. A anoxia, por outro lado, é letal para as sementes. O etanol é o principal produto do metabolismo anaeróbico das sementes. A perda de viabilidade das sementes parece estar associada ao rápido aumento na concentração de lactato após 24 h de anoxia ou 48 h de hipoxia.

Key words - Inga sessilis, germination, respiratory metabolism, hypoxia, anoxia

\section{Introduction}

In Southeastern Brazil, there are only two types of forests occurring in land-inland water ecotone: gallery and swampy forests. Gallery forests are subjected to periodic flooding (Reichardt 1989) and their floristic composition is characterized by some exclusive species and others that vary according to the adjacent forestall formation, usually semideciduous forests. Swampy forests, on the other hand, occur on permanently flooded areas and are characterized by a low number of arboreal species that usually present a wide geographic distribution within a well defined habitat, i.e. waterlogged soils (Leitão-Filho 1982).

Many studies and models show that the species composition of flooded areas can be explained by such factors as stream velocity and power, flooding duration, exposure to light, soil fertility as well as

1. Part of the MSc thesis of J.M. Okamoto.

2. Universidade Estadual de Campinas, Instituto de Biologia, Departamento de Botânica, Caixa Postal 6109, 13083-970 Campinas, SP, Brasil.

3. Corresponding author: cjoly@obelix.unicamp.br human intervention (Blom \& Voesenek 1996). Flooding triggers a quick disappearance of oxygen in the soil and imposes a heavy constraint to gas diffusion (Armstrong et al. 1994), as well as a compactation due to the breaking and rearranging of aggregate particles (Engelaar et al. 1993).

The stress caused by low oxygen availability induces a reduction in the synthesis of ATP, proteins and nucleic acids. Such modifications deeply affect the induction and genetic expression of various enzymes associated with the carbohydrate fermentative metabolism (Davies 1980, Mocquot et al.1981).

Tolerance to different oxygen concentrations found in environments subjected to flooding varies significantly among species. In the last twenty-five years, many studies have attempted to elucidate the strategy developed by plants, that enable them to germinate, grow and survive in such areas (Baskin \& Baskin 1976, Crawford, 1977, 1978, 1992, Davies 1980, Joly \& Crawford 1982, Joly 1991, 1994, 1996, Joly \& Brändle 1995).

Although seeds can also be subjected to hypoxia and anoxia, because they can fall in areas of waterlogged soil, be dispersed by water or may have a tegument impermeable to gases, studies on the influence of low oxygen availability have mainly focused on establishing seedlings. Exceptions are the species 
with economical interests, such as Pisum sativum L. (Smith \& Ap Rees 1979), Triticum aestivum L. (Waters et al. 1991), Oriza sativa L. and Echinochloa crus-galli L. (Kennedy et al. 1991) and Datura stramonium L. (Benvenutti \& Macchia 1995).

As a contrast, with Neotropical plants, studies have focused on arboreal species and brought forward a wide range of responses, such as the capacity of germinating under hypoxia, Inga affinis DC, Mimosaceae (Lieberg \& Joly 1993) and Sesbania virgata (Cav.) Pers., Fabaceae (J.M. Okamoto, unpublished data), and even anoxia, Chorisia speciosa St.Hil., Bombacaceae (Joly \& Crawford 1983); the avoidance strategy of seed dispersion and germination during the drier period of the year, Talauma ovata St.Hil., Magnoliaceae (Lobo \& Joly 1996); and the persistence of seed viability over long periods of hypoxia, Parkia pendula (Willd) Benth. ex Walpers, Mimosaceae (Scarano \& Crawford 1992) and Calophylum brasiliense Camb., Clusiaceae (M.C.M. Marques \& C.A. Joly, unpublished data).

The adaptive responses to low oxygen availability conditions may be considered along two research lines related to habitat. The first one looks into the variety of species present in a given habitat, i.e. species that, despite living together and facing similar environment conditions, present different adaptive responses. The second line of research focuses on species that are closely related, e.g. of the same genus, but occur along a gradient of waterlogging and show different strategies. These strategies may reflect the specific waterlogging conditions of the spot in which they grow, along the gradient (Blom \& Voesenek 1996).

The genus Inga is considered as typical of waterlogged areas because approximately $50 \%$ of its 350 plus species occur on areas where soil saturation with water and/or floods are frequent (Pennington 1997). Nevertheless, some species, as Inga sessilis, live in drier areas where the soil is well drained all year round. This paper aims at presenting the results of the changes in the respiratory metabolism of seeds of $I$. sessilis during germination under normoxia, hypoxia and anoxia as a tool to understand the evolution of the adaptations towards growth in waterlogged areas, present in most species of the genus.

\section{Material and methods}

Inga sessilis (Vell.) Mart. is a 12 to $20 \mathrm{~m}$ high tree, with a stem varying between 20 and $40 \mathrm{~cm}$ in diameter at breast height (Burkart 1979). It is typical from the semideciduous mesophytic forests from inland São Paulo State and grows in well-drained soils.

The seeds used in this study were obtained from fruits collected in the area known as Mirante (1170 m above sea level) at the Reserva Municipal da Serra do Japi (municipality of Jundiaí, State of São Paulo, $23^{\circ} 11^{\prime}$ S and $46^{\circ} 52^{\prime}$ $\mathrm{W})$. Vegetation in the Mirante area is classified as Semideciduos Mesophytic Altitudinal Forest and grows in a very shallow rocky soil, never subjected to waterlogging (Rodrigues et al. 1989; Leitão-Filho 1995).

Immediately after harvesting, the fruits were taken to the Laboratório de Ecofisiologia Vegetal do Departamento de Botânica (Instituto de Biologia, Universidade Estadual de Campinas) where the seeds were taken out of their pods and their white sarcotests were removed. Before starting each experiment, the seeds, without sarcotest, were surface sterilized by submersion, for $3 \mathrm{~min}$, in $100 \mathrm{~mL}$ of a 1000 units. $\mathrm{mL}^{-1}$ solution of Micostatin, a powerful fungicide, and then washed in running distilled water for $5 \mathrm{~min}$.

Normoxia conditions were obtained by placing the seeds in Gerbox lined with white filter paper saturated with distilled water. Hypoxia conditions were obtained by submerging the seeds in $250 \mathrm{~mL}$ of distilled water. Anoxia treatments were carried out placing the seeds in OXOID anaerobic jars. In all treatments 10 Gerboxes or Petri dishes with 10 seeds each were used.

All treatments (normoxia, hypoxia and anoxia) were carried out in FANEM germinators at $25 \pm 2{ }^{\circ} \mathrm{C}$ with $12 \mathrm{~h}$ white light photoperiod, and radicle protusion was considered as the indicator of germination. Seed photoblastism was tested only in normoxia conditions. Dark conditions were obtained by enveloping the Gerboxes in three black polyethylene bags, as described by Joly \& Felippe (1979). The dark experiment was started and seed germination was followed in a darkroom with green security light (Joly \& Felippe 1979).

The Gerboxes were examined every day and germinated or dead (putrefied) seeds were removed. The experiments were considered finished when $100 \%$ of the seeds had germinated or were dead. In the case of the anoxia treatment daily examination of the seeds, without opening the jars, was possible because the jars are transparent. Even so, after three, four, 10 and 40 days the jars were opened and the seeds carefully examined for radicle protusion.

Inga seeds are recalcitrants (Steadman et al. 1996) and start losing viability after $24 \mathrm{~h}$ when kept in bags at room temperature. Therefore, the seed longevity was tested by keeping the seeds stored in distilled water at $5^{\circ} \mathrm{C}$ 
in a refrigerator, in order to avoid desiccation and reduce the metabolic rate inhibiting germination.

Seed viability after being subjected to anoxia was tested for seeds kept in the anaerobic jars for half, one, two, three, four, 10 and 20 days. These anoxia treated seeds were removed from the jars, washed with distilled water and placed in Gerboxes lined with white filter paper saturated with distilled water, as in the normoxia treatments. These Gerboxes were examined every day and germinated or dead (putrefied) seeds were removed.

After the conversion of percentage to arc sen. of the square root of the percentage, average difference significance was tested with a Tukey test (Sokal \& Rohlf 1979).

In the experiments carried out to determine the level of etanol, lactate and malate in the germinating seeds kept under normoxia, hypoxia and anoxia for 12, 24, 48, 72 and $96 \mathrm{~h}$, after each period of treatment the seeds ( $\pm 1 \mathrm{~g}$ ) were placed in liquid nitrogen, and then triturated in $12 \mathrm{~mL}$ of chilled perchloric acid $(6 \%)$. The homogenate was centrifuged at 3,500 rpm during $20 \mathrm{~min}$ in a chilled centrifuge $\left(0{ }^{\circ} \mathrm{C}\right)$. After centrifugation, the supernatant was removed and neutralized with $5 \mathrm{M} \mathrm{K}_{2} \mathrm{CO}_{3}$. The enzymatic determination of ethanol and lactate was carried out using BOEHRINGER kits as described by Joly \& Brändle (1995). The loss of metabolites during extraction was estimated by adding known amount of ethanol and lactate to an additional sample of seeds. The average recovery figures were as follow: ethanol $84 \%$, lactate $93 \%$ and malate $91 \%$. In all cases there were five replicates per treatment, the results were analyzed by ANOVA and average differences significance were tested with a Tukey test (Sokal \& Rohlf, 1979).

\section{Results}

Inga sessilis seeds are not photoblastic, although the presence of light increases the speed of germination (figure 1). Hypoxia significantly delayed the start of germination, affected germination speed and significantly reduced the final percentage of germinated seeds from $100 \%$ under normoxia to approximately $40 \%$ (figure 1). Under anoxia there was a complete inhibition of seed germination (figure 1).

Approximately $30 \%$ of the seeds kept submerged in distilled water in the refrigerator lost their viability after five days. Increasing the storage period up to 20 days did not reduce further seed viability, but after 30 days in such conditions, all seeds were dead (figure 2). The germination percentage encountered for the seeds stored during 10 days was higher than that of the seeds stored during five days.

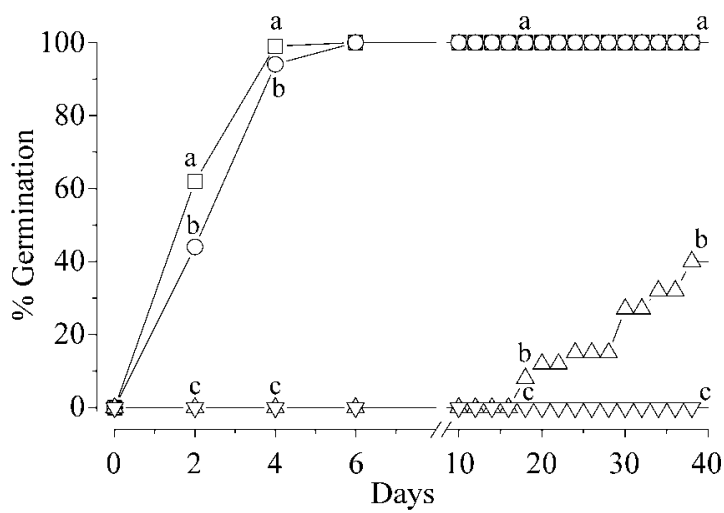

Figure 1. Germination potential of Inga sessilis seeds submitted to normoxia, hypoxia and anoxia. Means in the same column followed by the same letter do not differ among themselves through the Tukey test $(\mathrm{p}<0.05)$ with $\mathrm{n}=10$. ( $\square$ ) Normoxia under light; (o) nor-moxia in the dark; $(\Delta)$ hypoxia; $(\nabla)$ anoxia.

Seeds kept in the anaerobic jars for periods up to two days still are able to germinate when removed from anoxia and placed to germinate in Gerboxes kept in normoxia (figure 3). After three days in the anaerobic jars the seeds start to loose their capability to germinate after returning to a normoxia atmosphere. The longer the period the seeds are subjected to anoxia the lower the percentage of viable seeds and after 20 days in the jars all seeds are dead (figure 3).

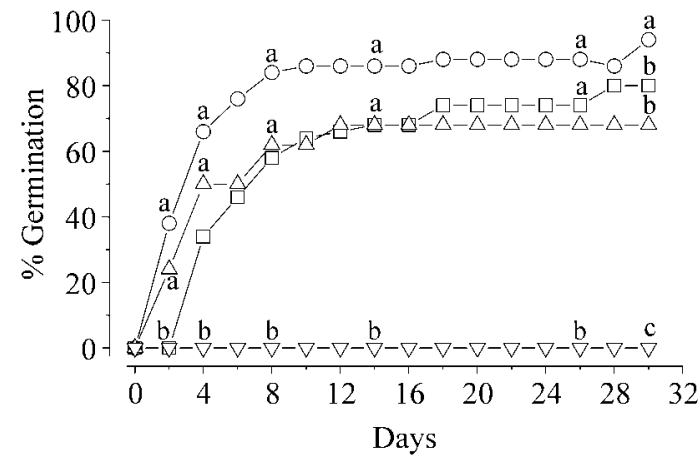

Figure 2. Germination percentage of Inga sessilis seeds stored during 5, 10, 20 and 30 days in water under low temperature conditions. Means in the same column followed by the same letter do not differ among themselves through the Tukey test $(\mathrm{p}<0.05)$ with $\mathrm{n}=10$. ( $\square$ ) Stored for 5 days; (o) stored for 10 days; $(\Delta)$ stored for 20 days; $(\nabla)$ stored for 30 days. 


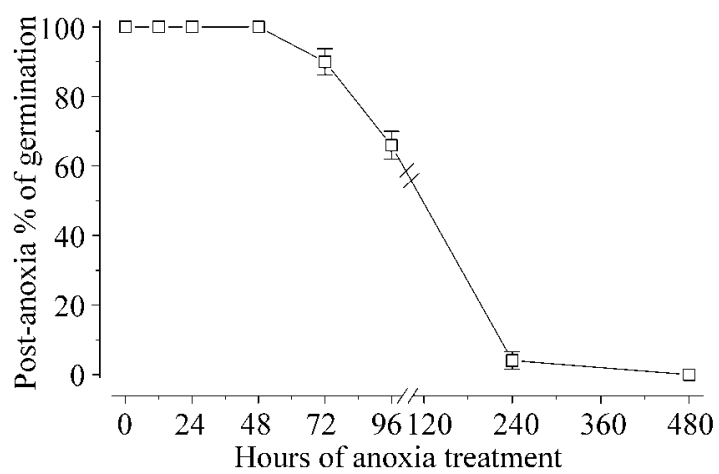

Figure 3. Germination of Inga sessilis seeds when returning to air after being subjected to $1 / 2,1,2,3,4,10$ and 20 days of anoxia in the anaerobic jars. Bars show confidence intervals at $95 \%$.

Figure 4A shows that the seeds of I. sessilis present a high initial concentration of ethanol with a sudden drop in the first $12 \mathrm{~h}$ of germination, regardless of the oxygen concentration. Thereafter, there were no significant changes in the amount present in the seeds kept under normoxia and hypoxia. The anoxia treated seeds, on the other hand, presented significantly higher levels of ethanol after 24 and $48 \mathrm{~h}$ in the anaerobic jars but, due to a steep drop after $72 \mathrm{~h}$, the final concentration of ethanol is similar in all treatments.

The reduction in the amount of oxygen available for germination had a marked influence on the pattern of lactate accumulation (figure 4B). While the seeds kept in normoxia did not present significant changes in lactate concentration, hypoxia and anoxia treated seeds presented a constant increase in the level of this metabolite, with a steeper increase in the anoxia incubated seeds.

On the other hand although there are changes in the amount of malate present in the seeds these are not correlated with the level of oxygen available (figure 4C).

\section{Discussion}

The germination percentage encountered for the seeds stored during 10 days was higher than that of the seeds stored during five days, which is consistent with the results of studies on stored seeds of Inga vera subsp. affinis (J.M. Okamoto \& C.A. Joly un-
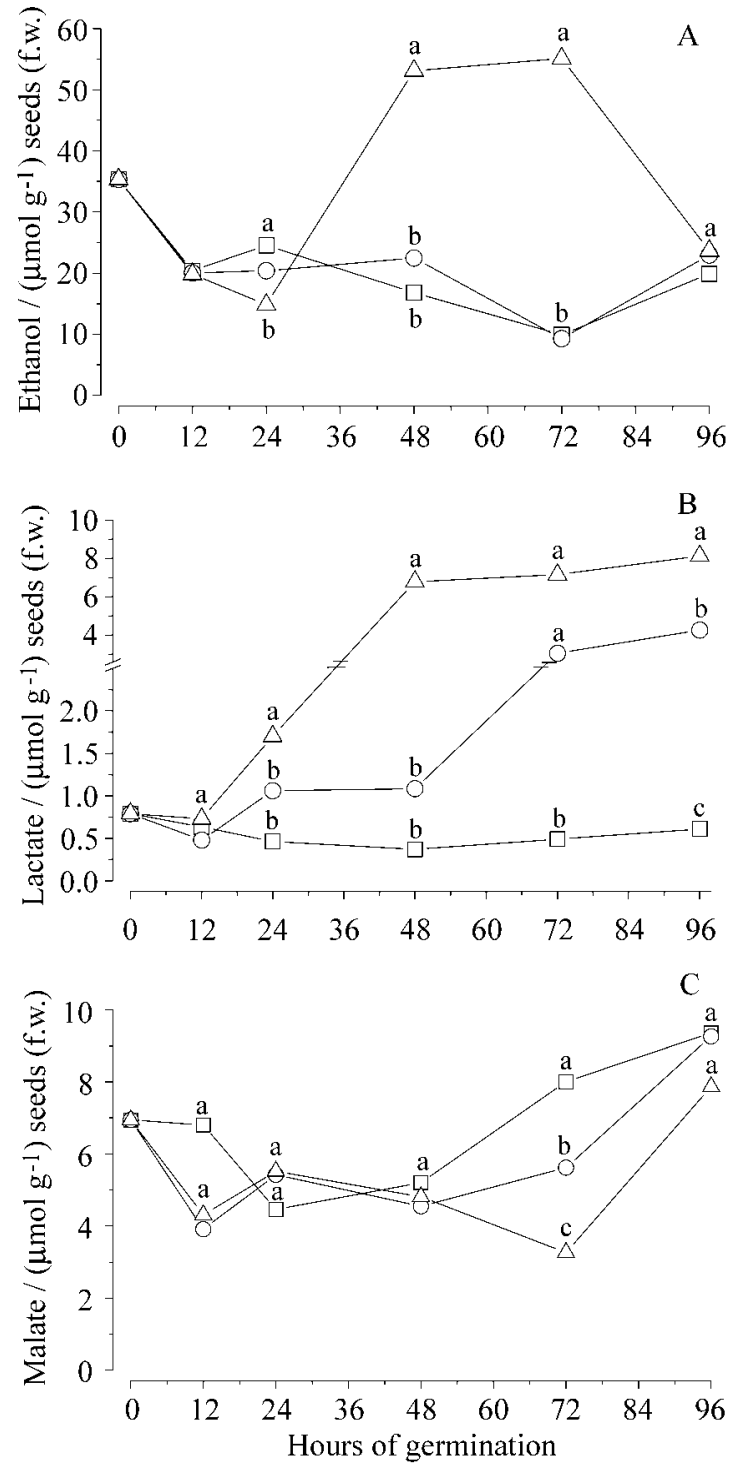

Figure 4. Ethanol (4A), lactate (4B) and malate (4C) concentrations during the germination of Inga sessilis seeds subjected to normoxia, hypoxia and anoxia. Means in the same column followed by the same letter do not differ among themselves through the Tukey test $(\mathrm{p}<0.05)$ with $\mathrm{n}=5$. ( $\square$ ) Normoxia; (o) hypoxia; $(\Delta)$ anoxia.

published data), where seeds stored for 30 days presented a higher germination potential than those stored for 20 days.

The germination potential of Inga sessilis seeds in normal oxygen conditions is high, attaining $100 \%$ 
after four days in the light and six days in the dark. Under hypoxia, germination was delayed, started only after 18 days of treatment, but only partially inhibited. Suprisingly, even though the native environment of Inga sessilis, mesophytic semideciduous forest, does not present any variation with regard to oxygen availability in the soil, approximately $40 \%$ of the seeds maintain their germination capacity in hypoxic conditions, thus suggesting a high plasticity.

Although the oxygen concentration inside the fruits was not measured, the high ethanol concentration observed at initial time may be the consequence of the Inga sessilis fruit characteristics, such as their thick, very fibrous shell, hindering gas exchanges with the environment thus configuring an almost anoxic atmosphere. Since these species seeds are viviparous, the fermentation pathway was probably already activated.

The decrease in ethanol concentration observed after $72 \mathrm{~h}$ under anoxia is probably related to the fact that the seeds start loosing their viability after that period of absence of oxygen, as shown in figure 3 .

The linear increase in the lactate concentration together with the seeds loss of viability after a time without oxygen corroborates the work by Roberts et al. (1985) which asserts that species able to control (tolerate or regulate) their cytoplasmic $\mathrm{pH}$ are more tolerant to flood than species devoid of that capacity.

Another possibility for the steep reduction in seed viability after three days of anoxia (figure 3 ) is the high amount of substrate used to keep ATP production through the fermentative pathways. We can suggest that seed viability decreases because the seeds are running out of storage carbohydrates due to the Pasteur effect (Crawford 1978).

Post-anoxia injury (Pfister-Sieber \& Brändle 1994) could be another reason to explain why Inga sessilis seeds kept under anoxia are unable to germinate when suddenly exposed to an atmosphere reach in oxygen.

The controversy as for malate production in plants tolerant to flood (Crawford 1978; Ap Rees et al. 1987) stimulated new research, as the recent studies by Joly $(1991,1994)$ who, based in Neotropical species, proposed that tolerance to flood depends on an interaction between metabolic responses (the reduction of the energetic demand and the control on the production of toxic metabolite as ethanol and lactate) and morpho-anatomic responses (the development of adventitious roots, aerenchyma and lenticel hypertrophy). The similarity in malate levels among the diverse treatments shows this is not a relevant alternative for seeds.

The studies carried out during the last 25 years have consensually revealed that plants and their seeds, as most of other organisms under low oxygen tension conditions as those found in flooded or completely waterlogged soils, substitute the fermentative metabolism for the aerobic respiration (Mc Mannon \& Crawford 1971, Davies 1980; Mocquot et al. 1981, Joly \& Crawford 1982, 1983, Raymond et al. 1985, Joly, 1991, 1994, Crawford 1992, Joly \& Brändle 1995, Crawford \& Brändle 1996), as observed in the seeds of Inga sessilis.

Concluding, the germination behavior and the respiratory metabolism show that this species is not highly tolerant to low oxygen availability. Nevertheless, it does show some tolerance, notwithstanding their occurrence in environments not subjected to waterlogging. This response leads to contradictory interpretations. Either Inga sessilis is developing mechanisms that will allow it to thrive in waterlogged areas, or the fact that $40 \%$ of its seeds are able to germinate under hypoxia is a mechanism that persisted, albeit it has long lost its function.

Some aspects brought forward by the present work, as the issue of the conservation of ancestral characteristics against acquisition of a derived feature, could only be elucidated through phylogenetic studies.

Acknowledgements - J.M. Okamoto was supported by a FAPESP MSc scholarship (97/01084-9) and C.A. Joly by a CNPq Research Fellowship (300362/96-0). The authors thank Miss Ana Lucia Moreira for technical assistance and Mr. Alain François for the English revision.

\section{References}

AP REES, T., JENKIN, L.E.T., SMITH, A.M. \& WILSON, P.M. 1987. The metabolism of flood-tolerant plants. In: Plant life in aquatic and amphibious habitats (R.M.M. Crawford, ed.). Blackwell Scientific Publications, Oxford, p.227-238. 
ARMSTRONG, W., BRANDLE, R. \& JACKSON, M.B. 1994. Mechanism of flood tolerance in plants. Acta Botanica Neerlandica 43:307-358.

BASKIN, J.M. \& BASKIN, C.C. 1976. Evidence for metabolic adaptation to flooding in Laevenworthia uniflora. Journal of Chemical Ecology 2:441-447.

BENVENUTTI, S. \& MACCHIA, M. 1995. Effect of hypoxia on buried weed seed germination. Weed Research 35:343-351

BLOM, C.W.P. \& VOESENEK, L.A.C.J. 1996. Flooding: the survival estrategies of plants. Tree 11:290-295.

BURKART, A. 1979. Leguminosas-Mimosoideae. In Flora Ilustrada Catarinense. (P.R. Reitz, ed.) Parte I, Herbário Barbosa Rodrigues, Itajaí, p.66-78.

CRAWFORD, R.M.M. 1977. Tolerance to anoxia and ethanol metabolism in germinating seeds. New Phytolologist 79:511-517.

CRAWFORD, R.M.M. 1978. Metabolic adaptations to anoxia. In Plant life in anaerobic environments (D. D. Hook \& R. M.M. Crawford, eds.). Sciense Publisher, Ann Arbor. p.119-154.

CRAWFORD, R.M.M. 1992. Oxygen availability as an ecological limit to plant distribution. Advances in Ecological Research 23:93-185.

CRAWFORD, R.M.M. \& BRÄNDLE, R. 1996. Oxygen deprivation stress in a changing environment. Journal of Experimental Botany 47:145-159.

DAVIES, D.D. 1980. Anaerobic metabolism and the production of organic acids. In The biochemistry of plants - a compreensive treatise (P.K. Stumpf \& E.E. Conn, eds), v.2: Metabolism and respiration. Academic Press, New York, p.581-611.

ENGELAAR, W.M.H., VAN BRUGEN, M.W., VAN DEN HOEK, W.P.M., HUYSER, M.A.H. \& BLOM, C.W.P.M. 1993. Roots porosities and radial oxygen losses of Rumex and Plantago species as influenced by soil pore diameter and soil aeration. New Phytologist 125:565-574.

JOLY, C.A. 1991. Flooding tolerance in tropical trees. In Plant life under oxygen deprivation: ecology, physiology and biochemistry (M.B.Jackson, D.D. Davies $\&$ H. Lambers, eds.). SBP Academic Publishing, The Hague, p.23-34.

JOLY, C.A. 1994. Flooding tolerance: a reinterpretation of Crawford's metabolic theory. Proceedings of the Royal Society of Edinburgh 102b:343-354

JOLY, C.A. 1996. The role of oxygen diffusion to the root system on the flooding tolerance of Brazilian trees. Revista Brasileira de Biologia 56:375-382
JOLY, C.A. \& BRÄNDLE, R. 1995. Fermentation and adenylate metabolism of Hedychium coronarium J.G. Koenig (Zingiberaceae) and Acorus calamus L. (Araceae) under hypoxia and anoxia. Functional Ecology 9:505-510.

JOLY, C.A. \& CRAWFORD, R.M.M. 1982. Variation in tolerance and metabolic responses to flooding in some tropical trees. Journal of Experimental Botany 33:799-809.

JOLY, C.A. \& CRAWFORD, R.M.M. 1983. Germination and some aspects of the metabolism of Chorisia speciosa St. Hil. seeds under anoxia. Revista Brasileira de Botânica 6:85-90.

JOLY, C.A. \& FELIPPE, G.M. 1979. Germinação e fenologia de Zeyhera digitalis: estudo preliminar. Hoehnea 8:35-40.

KENNEDY, R.A., FOX, T.C., EVERARD, J.D. \& RUMPHO, M.E. 1991. Biochemical adaptations to anoxia: potential role of mitochondrial metabolism to flood tolerance in Echinochloa phyllopogon (Barnyard grass). In Plant life under oxygen deprivation: ecology, physiology and biochemistry (M.B. Jackson, D.D. Davies \& H. Lambers, eds.). SBP Academic Publishing, The Hague, p.217-227.

LEITÃO-FILHO, H.F. 1982. Aspectos taxonômicos das florestas do estado de São Paulo. Silvicultura em São Paulo 16:197-206.

LEITÃO-FILHO, H.F. 1995. A vegetação da Reserva de Santa Genebra. In: Ecologia e preservação de uma floresta tropical urbana: Reserva de Santa Genebra (P.C. Morellato \& H. Leitão-Filho, eds.). UNICAMP, Campinas, p.19-29.

LIEBERG, S.A. \& JOLY, C.A. 1993. Inga affinis DC (Mimosaceae): germinação e tolerância de plântulas à submersão. Revista Brasileira de Botânica 16:175179.

LOBO, P.C. \& JOLY, C.A. 1996. Ecofisiologia da germinação de sementes de Talauma ovata St. Hil. (Magnoliaceae) uma espécie típica de Matas de Brejo. Revista Brasileira de Botânica 19:35-40.

McMANMOM, M. \& CRAWFORD, R.M.M. 1971. A metabolic theory of flooding tolerance: the significance of enzyme distribution and behavior. New Phytologist 70:299-306.

MOCQUOT, B., MOUCHES, C. \& PRADET, A. 1981. Effect of anoxia on energy charge and proteins synthesis in rice embryo. Plant Physiology 68:636-640.

PENNINGTON, T.D. 1997. The genus Inga. Royal Botanic Gardens, Kew.

PFISTER-SIEBER, M. \& BRÄNDLE, R. 1994. Aspects of plant behaviour under anoxia and post-anoxia. Proceedings of the Royal Society of Edinburgh 102b: 313-324. 
RAYMOND, P., AL-ANI, A. \& PRADET, A. 1985. ATP production by respiration and fermentation, and energy charge during aerobiosis and anaerobiosis in twelve fatty and starchy germinating seeds. Plant Physiology 79:879-884.

REICHARDT, K. 1989. Relações água-solo-planta em Mata Ciliar. In Simpósio sobre Mata Ciliar. (L.M. Barbosa, coord.). Fundação Cargil, Campinas, p.2024.

ROBERTS, J.K.M., ANDRADE, F.H. \& ANDERSON, I.C. 1985. Further evidence that cytoplasmic acidosis is a determinant of flooding intolerance in plants. Plant Physiology 77:492-494.

RODRIGUES, R.R., MORELLATO, L.P.C., JOLY, C.A. \& LEITÃO-FILHO, H.F. 1989. Estudo florístico e fitossociológico em um gradiente altitudinal de mata estacional mesófila semidecídua, na Serra do Japi, Jundiaí, SP. Revista Brasileira de Botânica 12:71-84.
SCARANO, F.R. \& CRAWFORD, R.M.M. 1992. Ontogeny and the concept of anoxia-tolerance: the case of the Amazonian leguminous tree Parkia pendula. Journal of Tropical Ecology 8:349-352.

SMITH, A.M. \& AP REES, T. 1979. Effects of anaerobiosis on carbohydrate oxydation by roots of Pisum sativum. Phytochemistry 18:1453-1458.

SOKAL, R.R. \& ROHLF, F. 1979. Biometria: principios y metodos estadisticos en la investigacion biologica. H Blume Ediciones, Madrid.

STEADMAN, K.J., PRITCHARD, H.W. \& DEY, P. 1996. Tissue specific soluble sugar in seeds as indicators of storage category. Annals of Botany 77:667674.

WATERS, I., KUIPER, P.J.C., WATKIN, E. \& GREENWAY, H. 1991. Effects of anoxia on wheat seedlings. I. Interaction between anoxia and other environmental factors. Journal of Experimental Botany 42:1427-1435. 